\title{
Fate and toxicity of ferric ferrocyanide with cyanogenic and non-cyanogenic plant species
}

\author{
Dong Hee Kang ${ }^{\dagger}$, Xuejun Qian ${ }^{2}$ \\ ${ }^{1}$ Department of Civil and Environmental Engineering, Morgan State University, 1700 East Cold Spring Lane, Baltimore, MD 212151, USA \\ ${ }^{2}$ Industrial and Systems Engineering Department, Morgan State University, 1700 East Cold Spring Lane, Baltimore, MD 21251, USA
}

\begin{abstract}
Iron cyanide complexes are common contaminants at former manufactured gas plant sites. Although combined forms of cyanide have low toxicity, iron cyanide complexes can be decomposed to $\mathrm{HCN}$ through photolysis. This experiment was designed to evaluate the efficiency of phytoremediation and investigate potential toxic effect for iron cyanide complexes (i.e., ferric ferrocyanide) using the cyanogenic and non-cyanogenic plants in soil. Results showed that Sorghum (a cyanogenic plant) had the highest cyanide degradation in the root zone with the removal of approximately $32 \%$ while Switchgrass (a non-cyanogenic plant) and Flax (a cyanogenic plant) had $21 \%$ and $17 \%$ removal, respectively, with $4 \%$ dissipation in unvegetated soil. It was found that roots had higher cyanide concentrations than plant shoots. Water-soluble cyanide and the weak acid dissociable (WAD) fraction in the soil had increased at the end of the experiment, suggesting that plant may enhance the mobility and bioavailability of cyanide by root exudation. The risk associated with the leaching of cyanide compounds was assessed with the toxicity assay (Microtox). However, results indicated that the leachate from the pots was not toxic
\end{abstract}

Keywords: Cyanide, Cyanogenic Plant, Ferric Ferrocyanide, Phytoremediation, Soil, Toxicity assay (Microtox)

\section{Introduction}

Although free cyanide is known to be toxic, combined forms of cyanide are common and have low toxicity [1]. Cyanide contaminated soils may be the result of a variety of industrial activities such as electroplating processes, road salt storage facilities, and gold mine tailings $[2,3]$. One of the most serious sources of cyanide is purifier wastes at former manufactured gas plant (MGP) sites. Activities at MGP facilities produced pollutants that have extensively contaminated surrounding soil and groundwater. These contaminants were produced in a gas purification box containing bog iron and iron ore. From the reactions of HCN with bog iron and iron ore, iron cyanide complexes, $\left[\mathrm{Fe}(\mathrm{CN})_{6}\right]$ were formed [1]. Some of previous studies found that iron cyanide complexes could be decomposed to HCN through photolysis [2, 4].

Phytoremediation, the use of plants and the associated rhizosphere microorganisms to remediate contaminated soil and groundwater, may be used as a low-maintenance remedial method [5]. Plant may assist with contaminant dissipation by accumulation and/or metabolism and may indirectly enhance biodegradation in the rhizosphere. There has been only limited evaluation of cyanide phytoremediation over the past few decades. Accumulation of cyanide compounds in Sorghum has been reported [6, 7]. Of note, the concentration of these cyanide compounds diminished with plant maturity. The fact that cyano-compounds were shown to decrease in Sorghum with time is a strong indicator of the plant's ability to degrade these compounds. In addition, dilution effects due to the plant biomass increase can be another potential reason for the deduction of these cyanide compounds. Moreover, willows have been evaluated for transport and metabolism of free cyanide and iron cyanide complexes [8-12]. Cyanide compounds can be taken up and metabolized by willows without phytotoxicity effects. Phytoremediation of cyanide by willow is considered to be ecologically safe due to the minimal fraction of cyanide bioaccumulation in the aerial tissues [8].

Several plants also contain and produce cyanide as a byproduct. Cyanogenic plant is the plants produce and contain Cyanogenic glycosides as natural plant toxins. Cyanogenic glycosides are cyanide compounds produced in some plants and microorganisms [13-16]. These glycosides can produce hydrogen cyanide in plants
This is an Open Access article distributed under the terms of the Creative Commons Attribution Non-Commercial License (http://creativecommons.org/licenses/by-nc/3.0/) which permits unrestricted non-commercial use, distribution, and reproduction in any medium, provided the original work is properly cited.

Copyright (C) 2022 Korean Society of Environmental Engineers
Received June 30, 2021 Accepted October 03, 2021

${ }^{\dagger}$ Corresponding author

E-mail: donghee.kang@morgan.edu

Tel: +1-443-885-4728 Fax: +1-443-885-8126

ORCID: 0000-0001-7669-1379 
and/or microorganisms [17]. The majority of these compounds is formed from protein amino acids [18-20] and may serve as precursors for amino acid and protein synthesis during seedling development [21]. Linamarin and lotaustralin are the predominant cyanogenic glucosides found in cassava and Flax [16, 18, 19, 21-27]. Dhurrin, present in Sorghum, is produced from a precursor of L-tyrosine [18, 20]. The role of cyanogenic glucosides in plants has been primarily attributed to plant defense against herbivores $[16,18,23,24]$. These compounds also may play a role in plant physiological processes. For instance, part of the exogenously applied nitrogenous inhibitors of respiration (i.e., KCN) was converted into cyanogenic glucosides and it is suggested that endogenous cyanogen might be involved and promoted the germination of cocklebur seeds [28]. Although HCN may protect plants from consumption, it also presents a risk to plant health. Many cyanogenic plants have been shown to be beneficial and detoxify the HCN. The HCN is converted to asparagine, which is incorporated into the metabolic cycle $[15,18,26]$. Information about the feasibility of phytoremediation for iron cyanide compounds using the cyanogenic and non-cyanogenic plants is limited. This study is to investigate and evaluate the efficiency of phytoremediation using several types of cyanogenic and non-cyanogenic plants during the greenhouse experiments. In addition, toxicity tests were used to assess the potential risk of contaminants in phytoremediation to the ecosystem.

\section{Materials and Methods}

\subsection{Soil Preparation}

Soil to be used in these experiments was collected from the Purdue University Agronomy Farm (Tippecanoe County, IN). The top 10 to $50 \mathrm{~cm}$ of soil was collected by soil cores and thoroughly analyzed by MDS Harris Laboratory (Lincoln, NE) for soil characteristics summarized in Table 1 [29]. The soil analysis indicates that soil electric conductivity is 0.68 millimhos per centimeter (mmhos/cm) while the total cation exchange capacity was 23.8 milliequivalents per 100 grams (meq/100g). After field collection, the soil sample was mixed, air-dried, and sieved to have less than $2 \mathrm{~mm}$ diameter. Previous study determined that the source and geological location influenced cyanide contamination, ranging from smaller than $0.005 \mathrm{mg} / \mathrm{kg}$ (unpolluted soil in American site) to 27,000 (electroplating facilities in Dutch Site) [30]. This study selected the maximum concentration of cyanide contamination at gas worksites of Dutch sites $(1,000 \mathrm{mg} / \mathrm{kg})$ to simulate the contaminated soil [30]. To contaminate the soil with concentrations of $1,000 \mathrm{mg} \mathrm{CN} / \mathrm{kg}, 3,932 \mathrm{mg}$ of ferric ferrocyanide was used and mixed with $2 \mathrm{~kg}$ of soil and placed in small pots $(10 \mathrm{~cm}$ diameter, $15 \mathrm{~cm}$ length). Initially, the soil was saturated to provide sufficient moisture for germination. Exactly $800 \mathrm{~mL}$ of water was required to saturate each pot initially. Soil water content was then maintained at approximately $25 \%$ mass based (w/w) during the experimental period.

\subsection{Plant Selection}

Plants classified as both cyanogenic and non-cyanogenic were initially evaluated for use in this study by germination and root growth studies. As shown in Table 2, the effect of cyanide compounds on germination rate and root growth for ten varieties of Sorghum, eight varieties of Switchgrass, and two varieties of Flax was evaluated for potential use [29]. This study was conducted to identify plants with the highest potential for phytoremediation of iron cyanide contaminated soil. Results indicated that P721Q Sorghum (Sorghum bicolor), Omega-Gold Flax (Linum usitatissimum), and Dacotah Switchgrass (Panicum virgatum L.) had more than 50\% germination percentage [29]. The statistical comparisons indicated that the rate of root growth for Sorghum species was not significantly different between the $1,000 \mathrm{mg} / \mathrm{kg}$ ferric ferrocyanide and control groups (no contaminants), although root growth for Switchgrass and Flax species generally decreased with increasing concentration of cyanide compounds. Cyanogenic plant species had relatively higher root growth than non-cyanogenic species [29]. Based on

Table 1. Soil Characteristics

\begin{tabular}{|c|c|c|c|c|}
\hline \multicolumn{5}{|c|}{ Metal content (mg/L) } \\
\hline Magnesium & Zinc & Manganese & Copper & Iron \\
\hline 677 & 4.8 & 11.1 & 1.8 & 43.2 \\
\hline \multicolumn{5}{|c|}{ Non-metal content $(\mathrm{mg} / \mathrm{L})$} \\
\hline Phosphorus & Potassium & Calcium & Sulfur & Sodium \\
\hline 62 & 233 & 3,473 & 28 & 55 \\
\hline \multicolumn{5}{|c|}{ Soluble Salts content (mg/L) } \\
\hline Calcium & Magnesium & Potassium & Sodium & Chloride \\
\hline 3,473 & 677 & 233 & 55 & 45 \\
\hline \multicolumn{5}{|c|}{ Size distribution (\%) } \\
\hline & Silt & Clay & Sand & \\
\hline & 66.4 & 19.6 & 14 & \\
\hline \multicolumn{5}{|c|}{ Other characteristics } \\
\hline Soil pH & Organic Matter (\%) & Cation exchange capacity (CEC) (meq/100g soil) & Electrical Con & y (mhos/cm) \\
\hline 6.9 & 2.8 & 23.8 & \multicolumn{2}{|c|}{0.68} \\
\hline
\end{tabular}


Table 2. Plant Varieties

\begin{tabular}{|c|c|c|c|}
\hline Species & Variety & Species & Variety \\
\hline \multirow{9}{*}{ Sorghum } & P89012 & \multirow{8}{*}{ Switchgrass } & Alamo \\
\hline & $P 721 Q$ & & Blackwell \\
\hline & $P 1447$ & & Sunburst \\
\hline & P964063 & & Cave-In-Rock \\
\hline & P1389 & & Dacotah \\
\hline & P1392B & & Cert. Path \\
\hline & P1408 & & Cert Trail \\
\hline & P1529 & & Nebraska \\
\hline & $\begin{array}{c}\text { P21 } \\
\text { ARK } 1097\end{array}$ & Flax & $\begin{array}{c}\text { Brown } \\
\text { Omega-Gold }\end{array}$ \\
\hline
\end{tabular}

Note: Sorghum and Flax - Cyanogenic Species, Switchgrass Non-cyanogenic Species

those results, one plant variety from each plant species was chosen to study and evaluate phytoremediation efficiency in iron cyanide contaminated soil: P721Q Sorghum (cyanogenic), Omega-gold Flax (cyanogenic), and Dacotah Switchgrass (non-cyanogenic)[29].

\subsection{Greenhouse Study Methods}

Two cyanogenic species (Sorghum and Flax) and one non-cyanogenic species (Switchgrass) were selected for this greenhouse study. Three replicates were prepared for each plant species under two different conditions, unvegetated group (uncontaminated with no plant) and control groups (uncontaminated with plant). Total 21 pots were used, and each pot was placed in the greenhouse under controlled conditions with an air temperature of $25^{\circ} \mathrm{C}$, relative air humidity of $80 \%$, and a light cycle of $12 \mathrm{~h}$. After one week to allow for germination, the moisture cover was removed, and the soil was maintained at $25 \%$ water content(w/w) by adding $500 \mathrm{~g}(500 \mathrm{~mL})$ of water into $2 \mathrm{~kg}$ of soil until the final sampling. The water content was measured and maintained by weighing the pots biweekly.

\subsection{Analysis of Cyanide}

Total cyanide analysis quantifies all cyanide present in the samples except thiocyanate and nitriles [31]. The concentration of total cyanide in soil and leachate was evaluated at the initial and final steps using the ion chromatography after distillation (APHP 4500- $\mathrm{CN}^{-}-\mathrm{C}$ ). A $500 \mathrm{~mL}$ of sample was added to a boiling flask along with a limited quantity of air. The air transferred HCN gas to a container containing $1 \mathrm{~N}$ sodium hydroxide first. Then, 2 $\mathrm{g}$ of sulfamic acid, $50 \mathrm{~mL}$ of $1+1$ sulfuric acid, and $20 \mathrm{~mL}$ of 2.5 $\mathrm{M}$ magnesium chloride was added to the air inlet tube, followed by distilled water. The solution was heated to boiling for 1 hour. The determination of cyanide concentration in the adsorption solution was performed by ion chromatography [32, 33].

Weak acid dissociable (WAD) cyanide that can be liberated as hydrogen cyanide after the addition of acetic acid (pH 4.5 to 6.0) is one component of the total cyanide. The acetate buffer contains zinc salts to precipitate iron cyanide compounds. WAD cyanide includes free cyanide, hydrogen cyanide, and complexes such as potassium cyanide, and copper, zinc, and nickel complexes that readily release free and hydrogen cyanide [9]. Water-soluble cyanide is measured to evaluate the risk of leaching. Determination of soluble cyanide requires $5 \mathrm{~g}$ of soil leaching with distilled water, then shaking for $16 \mathrm{~h}$ until solubility equilibrium is established. After settling, supernatants were analyzed by distillation methods after filtering through a $0.45 \mu \mathrm{L}$ syringe filter. The cyanide content of the leachate is indicative of the residual solubility of insoluble metal cyanides in the soil. To determine cyanide concentrations in the biomass, plants were first separated into the plant shoot and root sections. Plant samples were prepared by crushing biomass under exposure to liquid nitrogen prior to extraction in $2.5 \mathrm{M} \mathrm{NaOH}$. Exposure of plant tissue to liquid nitrogen increases the recovery of cyanide concentrations by rupturing cells [20,34] and improves measurement precision due to limited volatilization losses [35]. Then, plant tissue was extracted by the distillation method. All cyanide concentrations in the plants were measured using the ion chromatography.

\subsection{Toxicity Assay (Microtox)}

Toxicity assay (Microtox) tests were performed on soil and leachate collected from vegetated control pots. Leachate and soil samples from the pots were exposed to the luminescent bacterium (Vibrio fischeri) and response evaluated with a Model 500 Toxicity Analyzer (Azur Environmental, Carlsbad, CA). Freeze-dried bacterial pellets containing approximately $10^{6}$ cells were obtained from Strategic Diagnostics Inc (Newark, NJ).

After completion of the greenhouse study, the Microtox Solid Phase Toxicity (SPT) test was performed to determine the toxicity of contaminated soil [37]. Seven grams of soil samples collected from each pot were placed in an SPT container with $35 \mathrm{~mL}$ of $2 \% \mathrm{NaCl}$, vortexed, and used for a 1:2 dilution series with two controls. Luminescent bacteria were directly introduced into each tube. The sample was briefly mixed and incubated for $20 \mathrm{~min}$ at $15^{\circ} \mathrm{C}$ in a temperature-controlled water bath. After incubation, a SPT filtering device was inserted to separate solids from the liquid. The filtrate was transferred to a cuvette for the Microtox analyzer. Light emission was determined after $10 \mathrm{~min}$ at a stabilization temperature at $15^{\circ} \mathrm{C}$ [38].

The leachate samples were also collected to evaluate and assess toxicity at the beginning and end of each experiment using Microtox assay and published procedures, respectively [36]. Water was added to the columns and leachate collected over $24 \mathrm{~h}$. The samples were tested after $24 \mathrm{~h}$ of sunlight exposure to evaluate photolysis since iron cyanide complexes decompose under sunlight. The complexes collected in the leachate decomposed approximately $50 \%$ after $24 \mathrm{~h}$ of exposure to sunlight. The following method was applied to leachate samples. Exactly $250 \mu \mathrm{L}$ of Microtox osmotic adjustment solution was added to $2.5 \mathrm{~mL}$ of leachate samples. Each test involved four sequential 1:2 dilutions of the samples and one reagent control. After adding $10 \mu \mathrm{L}$ of the reconstituted reagent to the five sample dilutions, each leachate sample was measured for luminescence after a 0-, 5-, and 15-min incubation period [36]. The results are averages of triplicates for each treatment. The significance of differences between the treatments was evaluated by the preceding verification of homogeneity for the analysis of the variance (ANOVA). A detailed evaluation of the variance was carried out by the Student-Newman-Keuls test $(\mathrm{P}<0.05)$. 


\section{Results and Discussion}

The cyanide concentrations in different sections of the plant biomass are shown in Fig. 1(a) and Fig. 1(b). The concentrations in the roots were $400 \mu \mathrm{g} / \mathrm{g}, 358 \mu \mathrm{g} / \mathrm{g}$, and $377 \mu \mathrm{g} / \mathrm{g}$ based on the dry weight of Switchgrass, Sorghum, and Flax, respectively. The results of the statistical analysis showed that cyanide concentrations in root tissues were not significantly different based on plant species. These concentrations are similar to willow reported by Ebbs et al. [8]. Cyanide concentrations in the roots of Switchgrass were also similar to previously reported values [8, 9, 38]. For the cyanogenic plants, cyanide concentrations in root biomass are not different with non-cyanogenic plant. This value is higher than the cyanide concentrations found in Sorghum bicolor [9]. However, Al-Sultan [39] found cyanide concentrations in Sorghum halepenses in the range of $0.42 \sim 25.4 \mu \mathrm{g} \mathrm{CN} / \mathrm{g}$, depending on the stage of growth. In the plant shoots, Flax had approximately three times higher concentration (57 $\mu \mathrm{g} \mathrm{CN} / \mathrm{g})$ than Switchgrass (17 $\left.\mu \mathrm{g} \mathrm{CN}^{-} / \mathrm{g}\right)$ and Sorghum (16 $\mu \mathrm{g} \mathrm{CN} / \mathrm{g}$ ) based on the dry weight. Cyanide concentrations in plant shoots were significantly different for each species $(\mathrm{P}<0.01)$. Comparable cyanide concentrations in Populus spp. leaves were reported under hydroponic conditions (186 mg CN/L). The concentrations of cyanide in roots were generally higher than in shoot biomass [8, 12]. Of note is that Switchgrass and Sorghum had more vigorous root growth than Flax. Fig. 1(c) shows the total cyanide concentration in soil. Given the 1,018 $\mu \mathrm{g} / \mathrm{g}$ initial cyanide concentration, the concentrations remaining after 4 months were $790 \mu \mathrm{g} \mathrm{CN} / \mathrm{g}$ in Switchgrass, $688 \mu \mathrm{g} \mathrm{CN}^{-} / \mathrm{g}$ in Sorghum, $830 \mu \mathrm{g}$ $\mathrm{CN}^{-} / \mathrm{g}$ in Flax, and $975 \mu \mathrm{g} \mathrm{CN} / \mathrm{g}$ in the unvegetated pots. Based on the ANOVA results, total cyanide concentrations in soil were significantly different based on treatments $(\mathrm{P}<0.05)$. Of note is that Sorghum, one of the cyanogenic plants, had higher cyanide degradation when compared to Switchgrass and Flax.

The overall mass balance based on cyanide is shown in Table 3. In the vegetated and unvegetated pots, $68.5 \%$ (Sorghum), $78.7 \%$ (Switchgrass), 82.2\% (Flax), and 96.2\% (unvegetated) of cyanide were recovered at the end of the experiment. The removal mechanisms

Table 3. Overall Mass Balance of Cyanide after 4 Months (dry weight, \%)

\begin{tabular}{lcccc}
\hline & Sorghum & Switchgrass & Flax & Unvegetated \\
\hline \multirow{2}{*}{ Soil } & $67.63^{*}$ & 77.66 & 81.61 & 95.82 \\
& $( \pm 2.59)^{* *}$ & $( \pm 4.28)$ & $( \pm 4.85)$ & $( \pm 8.50)$ \\
Root & 0.35 & 0.59 & 0.19 & $-^{* * *}$ \\
\multirow{3}{*}{ Plant Shoot } & $( \pm 0.02)$ & $( \pm 0.09)$ & $( \pm 0.00)$ & \\
& $( \pm 0.00)$ & 0.05 & 0.10 & - \\
Biomass & $( \pm 0.01)$ & $( \pm 0.02)$ & \\
\multirow{2}{*}{ Leachate } & 0.40 & 0.64 & 0.29 & - \\
& $( \pm 0.02)$ & $( \pm 0.10)$ & $( \pm 0.02)$ & \\
\multirow{2}{*}{ Total Recovery } & 0.45 & 0.37 & 0.42 & 0.39 \\
& $( \pm 0.00)$ & $( \pm 0.06)$ & $( \pm 0.00)$ & $( \pm 0.01)$ \\
& $( \pm 1.29)$ & $( \pm 2.11)$ & $( \pm 2.42)$ & $( \pm 6.00)$ \\
\hline
\end{tabular}

\footnotetext{
* Percentage calculated based on initial cyanide concentration ** Standard deviation

${ }^{* * *}$ Not available

${ }^{* * * *}$ Biomass are sum of root and plant shoot
}

include mineralization by respiration of plants and microbes, and plant uptake [5]. Approximately 67.6\% (Sorghum), 77.7\% (Switchgrass), and 81.6\% (Flax) of cyanide were recovered in soil of vegetated pots, while $95.8 \%$ of cyanide was recovered in the soil of unvegetated pots by the end of the experiment. The cyanide recovered from plant biomass was only $0.29 \%$ to $0.64 \%$ of the initial cyanide concentration. Concentration and mass of cyanide compounds changed with time because concentration of these cyanide compounds diminished with plant maturity can be degradation and dilution effects of plant biomass was increased. This result implies that cyanide is degraded rather than accumulated [8]. Changes in total cyanide in the soil indicate modification of
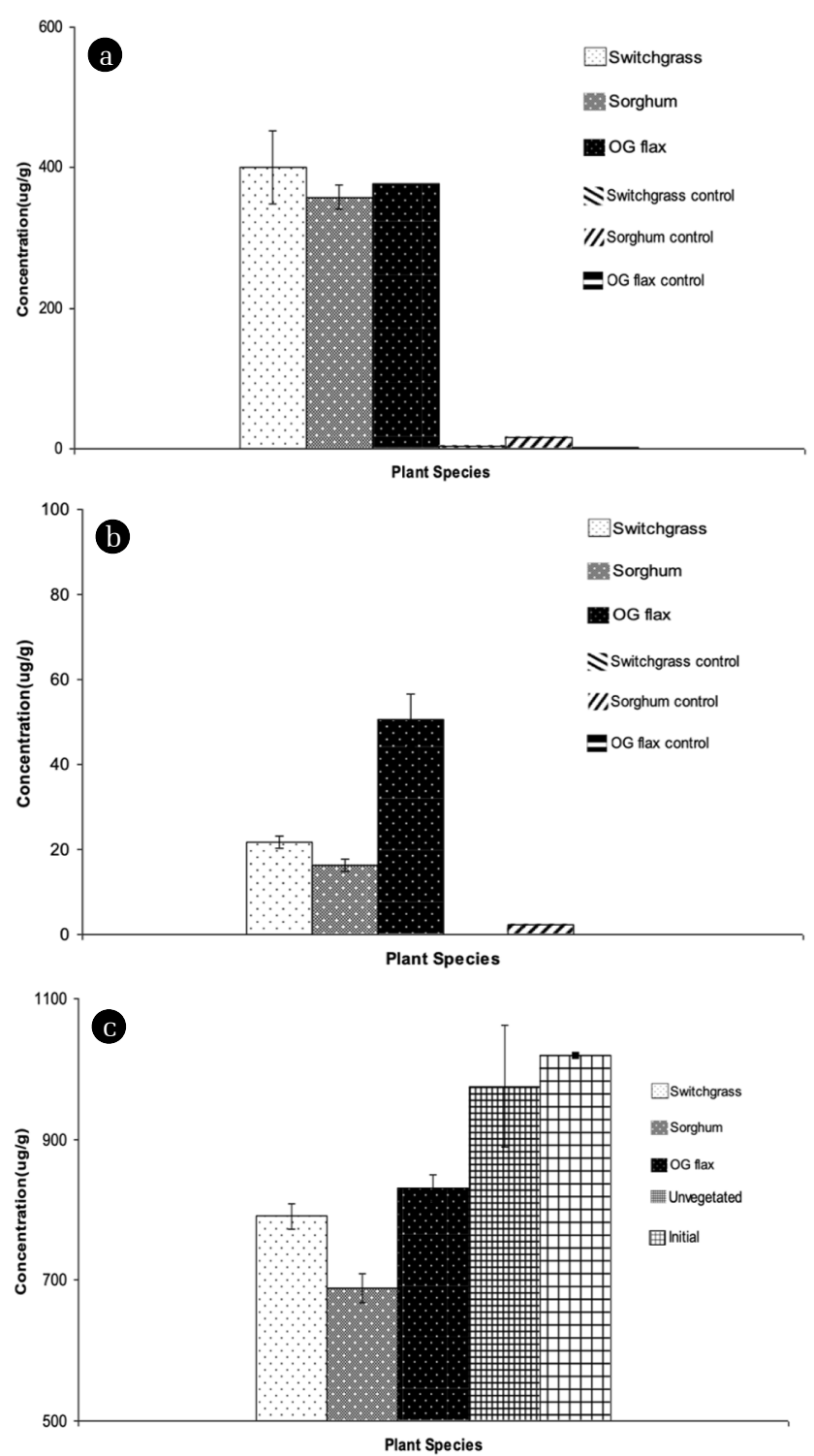

Fig. 1. Cyanide concentrations in plant biomass and soil samples after 4 months of exposure to $1,000 \mathrm{mg} / \mathrm{kg}$ total cyanide $(\mathrm{n}=3)$ : (a) Cyanide concentrations in roots, (b) Cyanide concentrations in plant shoots, and (c) Cyanide concentrations in soil samples. 
contaminants, but this measurement provides no insight into the bioavailability or mobility of cyanide compounds. Elements in the soil are associated with a number of physicochemical forms that influence bioavailability [40]. Adsorbed cyanide compounds onto soil surfaces significantly affect the potential for plant uptake, leaching, volatilization, and decomposition. Adsorbed elements reduce the bioavailability of pollutants and may contribute to a lack of apparent biodegradation. Results also indicated that the cyanide recovered from leachate under different conditions were less than $0.5 \%$ and both are less than $1 \%$ of the initial cyanide concentration. These findings suggest conducting future research to study cyanide degradation by plant assimilation and microorganism.

Water-soluble cyanide that could be removed by plants through transpiration was extracted from the soil at the end of the experiment. Even though iron cyanide compounds have limited bioavailability due to their stability and low dissociation ability [41], previous studies have reported that iron cyanide can be degraded by microbes isolated from contaminated sites [42, 43] and taken up and/or metabolized by plants [7, 8, 12]. Fig. 2(a) shows water-soluble cyanide concentrations in soil and Fig. 2(b) presents the percentage of water soluble and residual cyanide. It was found that $31.9 \%, 44.2 \%$, $22.4 \%$, and $19.2 \%$ of water-soluble cyanide concentration was detected in Switchgrass, Sorghum, Flax, and unvegetated soil, respectively. It can be found that water-soluble cyanide concentrations are significantly correlated to plant species based on the results of the ANOVA test $(\mathrm{P}<0.001)$ [44]. As noted, contaminated soil in the Sorghum and Switchgrass pots had higher soluble cyanide concentrations than Flax and unvegetated soil. Water-soluble cyanide concentration in planted soil may be affected by low molecular weight organic acids. Release of organic acids from roots can contribute to the acidification of the rhizosphere and promotes mineral dissolution by forming soluble metal complexes, thereby increasing ion availability for uptake by roots [45].

As shown in Fig. 3, the free and potentially dissociable cyanide was estimated along with cyanide speciation. Fig. 3(a) shows weak acid dissociable (WAD) cyanide concentration in soil and Fig. 3(b) shows average fraction of WAD. This fractionation was conducted using a WAD procedure that does not recover $\mathrm{CN}$ from the strong complexes with metals such as $\mathrm{Fe}, \mathrm{Co}, \mathrm{Ag}$, and Au that are very stable and not toxic. The toxicity of the weaker complexes is com- paratively higher than stronger complexes [46]. WAD cyanides are relatively unstable complexes composed of cyanide and transition metals (including $\mathrm{Cd}, \mathrm{Cu}, \mathrm{Ni}$, and $\mathrm{Zn}$ ) and dissociate under neutral or mildly acidic conditions to $\mathrm{CN}^{-}$. Approximately $23 \mu \mathrm{g} / \mathrm{g}$, $26 \mu \mathrm{g} / \mathrm{g}, 14 \mu \mathrm{g} / \mathrm{g}$, and $16 \mu \mathrm{g} / \mathrm{g}$ of weak acid dissociable cyanide was detected in Switchgrass, Sorghum, Flax, and unplanted soil, respectively. Based on statistical comparisons, weak acid cyanide concentrations are significantly different based on plant species

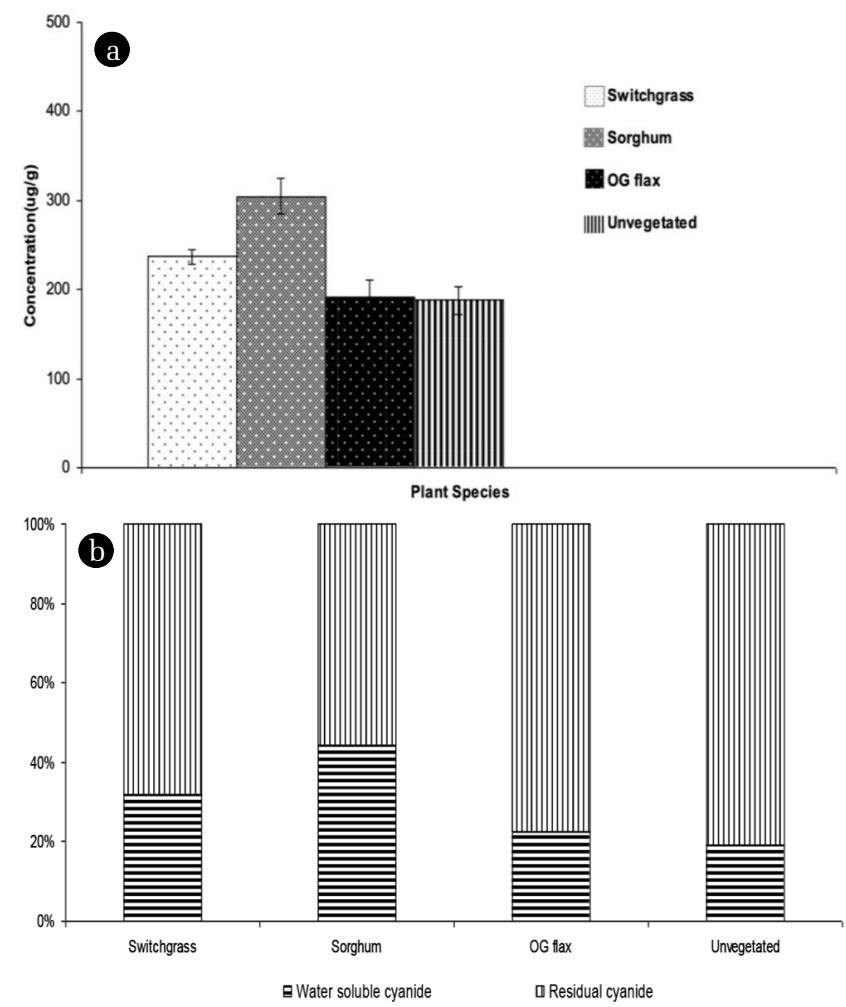

Fig. 2. Water soluble cyanide concentrations in soil after 4 months of exposure to $1,000 \mathrm{mg} / \mathrm{kg}$ total cyanide $(\mathrm{n}=3)$ : (a) Water soluble cyanide concentrations in soil samples, and (b) Average fraction of water-soluble cyanide (bottom section of each bar).

Table 4. $\mathrm{EC}_{50}(\%)$ and Cyanide Concentration of Leachate

\begin{tabular}{|c|c|c|c|c|c|}
\hline \multirow{2}{*}{ Condition } & \multirow{2}{*}{$\begin{array}{l}\text { Concentration } \\
\left(\mathrm{mg} \mathrm{CN}^{-} / \mathrm{kg}\right)\end{array}$} & \multicolumn{2}{|c|}{ Initial } & \multicolumn{2}{|c|}{ Final } \\
\hline & & $\mathrm{EC}_{50}(\%)$ & $\operatorname{Conc}(\mathrm{mg} / \mathrm{L})$ & $\mathrm{EC}_{50}(\%)$ & Conc $(\mathrm{mg} / \mathrm{L})$ \\
\hline \multirow{2}{*}{ Unvegetated } & Control & $-^{*}$ & 0 & - & 0 \\
\hline & 1,000 & 3.62 & 395.05 & - & 1.49 \\
\hline \multirow{2}{*}{ Sorghum } & Control & - & 0 & - & 0 \\
\hline & 1,000 & 2.82 & 428.83 & 398.5 & 14.51 \\
\hline \multirow{2}{*}{ Switchgrass } & Control & - & 0 & - & 0 \\
\hline & 1,000 & 2.22 & 374.78 & - & 3.99 \\
\hline \multirow{2}{*}{ Flax } & Control & - & 0 & - & 0 \\
\hline & 1,000 & 2.47 & 394.40 & 255.2 & 16.45 \\
\hline
\end{tabular}

*EC50 (\%) is greater than leachate concentration (non-toxic)

Note: The leachate samples were collected at the beginning and end of each experiment. Samples were tested after $24 \mathrm{~h}$ of sunlight exposure to evaluate photolysis effects. 

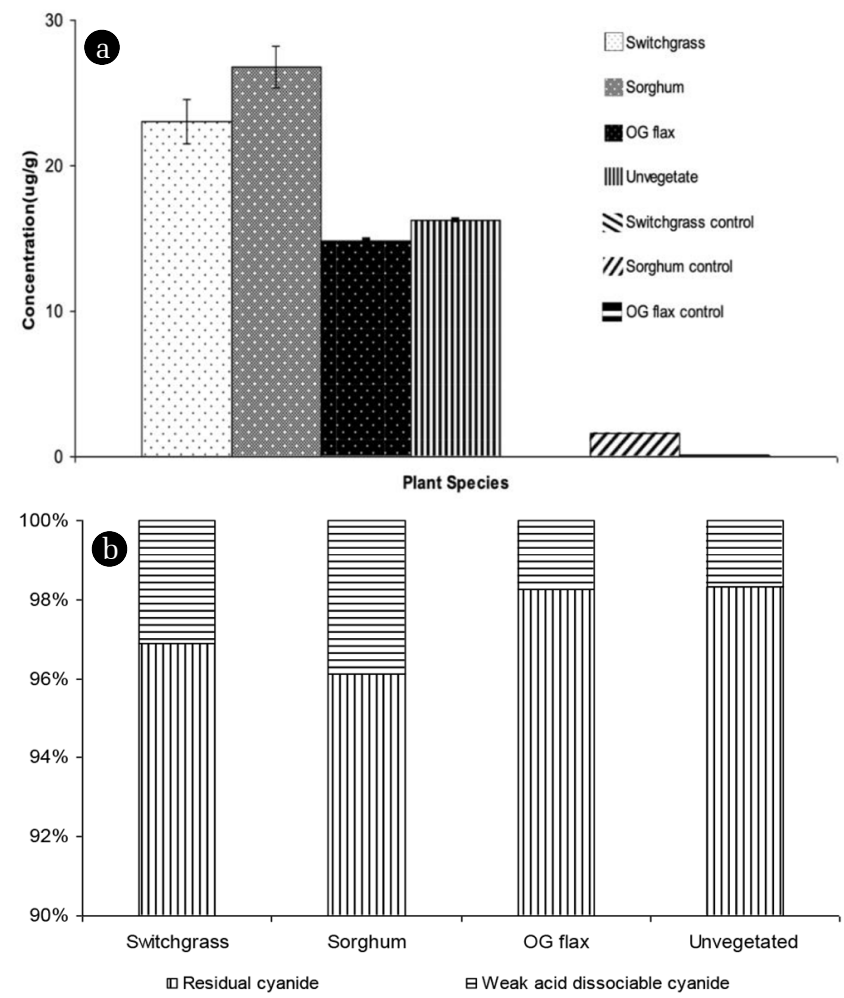

Fig. 3. Cyanide concentrations in soil after 4 months of exposure to $1,000 \mathrm{mg} / \mathrm{kg}(\mathrm{n}=3)$ : (a) Weak acid dissociable cyanide concentrations in soil, and (b) Average fraction of weak acid dissociable cyanide. Note: Strongly complexed cyanide such as ferric and ferrocyanide is represented by the difference between the total cyanide (100\%) and the weak acid dissociable cyanide (top section of each bar).

( $\mathrm{P}<0.001)$. Sorghum and Switchgrass pots had higher WAD cyanide concentrations than Flax and unvegetated soil, which is similar to results found for water-soluble cyanide concentrations. WAD cyanide concentration in planted soil may be affected by exudation of low molecular weight organic acids in the rhizosphere such as oxalate, citrate, and malonate. These compounds may enhance mobilization and promote mineral dissolution due to the accumulation of exudate compounds that act as adsorption competitors in the rhizosphere [47, 48].

As shown in Table 4, leachate samples showed that the $\mathrm{EC}_{50}$ of the leachate taken at the beginning of the study had a similar value when compared with liquid containing free or simple cyanide compounds. The toxicity of the samples that were not exposed to light indicated low levels of toxicity. Compared with initial leachate data, $\mathrm{EC}_{50}$ was increased to higher number and concentration was decreased at final leachate. $\mathrm{EC}_{50}$ of final leachate is larger than final concentration which means less toxic (non-toxic). Leachate containing ferric ferrocyanide rapidly decomposes and produces free cyanide when exposed to light. This result was expected based on previously published literature [2]. Leachate collected after 4 months of plant growth had significantly lower concentrations of cyanide than at the beginning of the study. This is
Table 5. $\mathrm{EC}_{50}(\%)$ of Soil Samples

\begin{tabular}{lc}
\hline & EC $_{50}(\%)$ \\
\hline Switchgrass $($ Dacotah $)$ & $0.022( \pm 0.003)$ \\
Sorghum $(P 721 Q)$ & $0.017( \pm 0.008)$ \\
Flax $($ Omega-Gold $)$ & $0.026( \pm 0.005)$ \\
Contaminated soil without plant & $0.032( \pm 0.011)$ \\
Uncontaminated soil with plant & $0.066( \pm 0.010)$ \\
\hline
\end{tabular}

Note: Microtox Solid Phase Toxicity (SPT) test was conducted after 4 months of phytoremediation treatment on soil containing $1,000 \mathrm{mg} / \mathrm{kg}$ total cyanide.

due to the fact that the leachability of cyanide diminishes in aged soil [49]. The $\mathrm{EC}_{50}$ values of leachate collected from Sorghum and Flax pots were high (higher than 100\%), implying that the cyanide concentration in the leachate did not contribute to toxicity. Leachate from the cyanogenic plants (Sorghum and Flax) had slightly higher concentrations than those from non-cyanogenic plants (Switchgrass). In addition, pots with plants produced leachate with higher concentrations of cyanide than the unvegetated pots. Mansfeldt et al. [50] assessed the effects of organic ligands (specifical citrate) on the mobilization and leaching of cyanides from contaminated soils. Even though the authors used higher citrate levels than would be found under environmental conditions root exudation could possibly increase cyanide leachability in the rhizosphere.

A toxicity assessment based on the Microtox SPT [3] was conducted on soil collected from all treatments to assess relative toxicity reduction. From Fig. 1 and Table 5, it can be seen that the total cyanide concentrations in soils of the unvegetated pots at the end of the experiment was higher compared with and planted pots. The possible reason maybe phytoremediation utilizes plants and associated organisms to degrade or immobilize contaminants in soil. Previous study also found similar results that the planted soil (6 7\%) stimulated high percentage of cyanide was converted to $\mathrm{CO}_{2}$ than the unplanted soil $(2 \%)$ and resulted lower cyanide concentration [33]. In addition, $\mathrm{EC}_{50}$ values were lower in vegetated pots than unvegetated pots. Soil toxicity was highly correlated to water-soluble and weak acid cyanide concentration in soil. Understanding the transport and fate of cyanide containing compounds as well as possible toxicity reduction alternatives are critical to develop new technologies for remediating cyanide contaminated soils or ground water from various sources (e.g., gas work sites, electroplating factories, road salt storage facilities, gold mine tailings, and others) Change to [29].

\section{Conclusions}

This experiment was conducted to evaluate the efficiency of phytoremediation and assess the risk of cyanide leaching during the clean-up process. Biomass analysis indicated that root section of biomass has higher cyanide concentrations than plant shoots section. After 4 months of plant growth, soil cyanide concentration was reduced approximately 17 32\% compared with initial soil and the unvegetated pots. Sorghum, one of the cyanogenic plants, had higher cyanide degradation. Water-soluble cyanide concen- 
trations in soil at the end of the experiment indicated that vegetation may increase the mobility of cyanide compounds. Low molecular weight organic acids can contribute to the acidification and increase mineral dissolution by forming soluble metal complexes and promote mineral dissolution in the rhizosphere. Therefore, low molecular weight organic acids may enhance the bioavailability of iron cyanide compounds. In addition, the analysis of samples indicated that the leachate taken at the end of the study was non-toxic and had very low cyanide concentration.

\section{Author Contributions}

D.H.K. (Assistant Professor) conducted all the experiments and wrote the manuscript. X.Q. (Postdoctoral Researcher) supported to format and revise manuscript.

\section{References}

1. Shifrin NS, Beck BD, Gauthier TT, Chapnick SD, Goodman G. Chemistry, toxicology, and human health risk of cyanide compounds in soils at former manufactured gas plant sites. Regulatory Toxic. Pharmacol. 1996;23:106-116.

2. Meeussen JCL, Keizer MG, van Riemsdijk WH, de Haan FAM. Solubility of cyanide in contaminated soils. J. Environ. Qual. 1994;23:785-792.

3. Kjeldsen P. Behavior of cyanides in soil and groundwater: A Review. Water Air Soil Poll. 1999;115:279-307.

4. Rader WS, Solujic L, Milosavljevic EB, Hendrix JL, Nelson JH. Sunlight-induced photochemistry of aqueous solutions of hexacyanoferrate(II) and-(III) ions. Environ. Sci. Technol. 1993;27: 1875-1879.

5. Banks MK, Lee E, Schwab AP. Fate of benzoa]pyrene in the rhizosphere of festuca arundinacea. J. Environ. Qual. 1999;28: 294-298.

6. Trapp S, Larsen M, Pirandello S, Danquah-Boakye J. Feasibility of cyanide elimination using plants. Eur. J. Min. Proc. Environ. Prot. 2003;3(1):128-137.

7. Samiotakis M, Ebbs SA. Possible evidence for transport of an iron cyanide complex by plants. Environ. Pol. 2004;127:169-173.

8. Ebbs SD, Bushey J, Poston S, Kosma D, Samiotakis M, Dzombak D. Transport and metabolism of free cyanide and iron cyanide complexes by willow. Plant Cell Environ. 2003;26:1467-1478.

9. Trapp SA, Christiansen JH. Phytoremediation of cyanide-polluted soils. In: Steven CM, Jerald LS, eds. Phytoremediation. Chichester, UK: John Wiley \& Sons Ltd.; 2003. p.829-862.

10. Larsen M, Trapp S, Pirandello A. Removal of cyanide by woody plants. Chemosphere 2004;54:325-333.

11. Yu X, Trapp S, Zhou P. Phytotoxicity of cyanide to weeping willow trees. Environ. Sci. Pollut. Res. Int. 2005;12(2):109-113.

12. Larsen M, Trapp S. Uptake of iron cyanide complexes into willow trees. Environ. Sci. Technol. 2006;40:1956-1961.

13. Fuller WH. Cyanides in the environment with particular attention to the soil. In: van Zyl D, eds. Proceedings of the Conference on Cyanide and the Environment, Fort Collins; 1985. p. 19-46.

14. Halkier BA, Scheller HV, Moller B. Cyanogenic glucoside: The biosynthetic pathway and the enzyme system involved. In: Evered D, Harnett S, eds. Cyanide Compounds in Biology. Chichester, UK: John Wiley \& Sons Ltd.; 1988. p. 49-66.

15. Miller JM, Conn EE, Metabolism of hydrogen cyanide by higher plants. Plant Physiol. 1980;65:1199-1202.

16. Vetter J. Plant cyanogenic glycosides. Toxicon 2000;38:11-36.

17. Towill LE, Drury JS, Whitfield BL, Lewis EB, Galyan EL, Hammons A. Review of the environmental effects of pollutants: V. Cyanide. No. ORNL/EIS-81; EPA-600/1-78-027. Oak Ridge National Lab., TN (USA);1978.

18. Conn EE. Cyanogenic compounds. Ann. Rev. Plant Physiol. 1980;31:433-451.

19. Du L, Bokanga M, Moller B, Halkier B. The biosynthesis of cyanogenic glucosides in roots of cassava. Phytochem. 1995;39:323-326.

20. Halkier B, Moller B. The biosynthesis of the cyanogenic glucoside dhhurrin in seedlings of Sorghum bicolor (L.) moench and partial purification of the enzyme system involved. Plant Physiol. 1989;90:1552-1559.

21. Niedzwidez-Siegien I. Cyanogenic Glucosides in Linum usitatissimum. Phytochem 1998;1:59-63.

22. Cutler AJ, Conn EE. The synthesis, storage, and degradation of plant natural products: Cyanogenic glycosides as an example. Phytochem 1982;16:249-271.

23. Nahrstedt A. Cyanogenic compounds as protecting agents for organisms. Syst. Evol. 1985;150:35-47.

24. Harborne J, Baxter H. Phytochemical dictionary: a handbook of bioactive compounds from plants. Washington, DC: Taylor \& Francis; 1993. p. 84-89.

25. O’Brien G, Wheatley C, Iglesias C, Poulter N. Evaluation, modification and comparison of two rapid assays for cyanogens in cassava. J. Sci. Food Agric. 1994;65:391-399.

26. Nambisan B, Sundaresan S. Distribution of linamarin and its metabolising enzymes in cassava tissues. J. Sci. Food Agric. 1994;66:503-507.

27. White L, Arias-Garzon D, McMahon J, Sayre R. Cyanogenesis in Casava. Plant Physiol. 1998;166:1219-1225.

28. Vetter J. Plant cyanogenic glycosides. Toxicon 2000;38(1):11-36.

29. Kang DH, Hong LY, Schwab AP, Banks MK. Plant germination and growth after exposure to iron cyanide complexes. J. Environ. Sci. Health Part A, 2008;43(6):627-632.

30. Kjeldsen, P. Behaviour of cyanides in soil and groundwater: a review. Water Air Soil Pollut. 1999;115(1):279-308.

31. Knowles C, Wyatt J. Microbial Control of Pollution, Cambridge, UK: Cambridge University Press; 1992. p.113-128.

32. Kang DH, Schwab AP, Johnston CT, Banks MK. Adsorption of iron cyanide complexes onto clay minerals, manganese oxide, and soil. J. Environ. Sci. Health A. Tox. Hazard Subst. Environ. Eng. 2010;45(11):1391-1396.

33. Kang DH, Lee YH, Schwab AP, Banks MK. Removal of Prussian blue from contaminated soil in the rhizosphere of cyanogenic plants. Chemosphere 2007;69(9):1492-1498.

34. Lechtenberg M, Nahrstedt A. Cyanogenic glycosides; naturally occurring glycosides. Chichester, UK: John Wiley \& Sons Ltd.; 1999. p. 147-191.

35. Bushey JT, Ebbs SD, Dzombak DA. Plant tissue extraction method for complexed and free cyanide. Water Air Soil Pollut. 
2004;157:281-293.

36. Azur Environmental Ltd. Comparison test protocol for Microtox 500 analyzer. Azur Environmental Ltd., Wokingham, U.K. 1998.

37. Johnson BT, Long ER. Rapid toxicity assessment of sediments from large estuarine ecosystems: A new tandem in vitro testing approach. Environ. Toxicol. Chem. 1998;17:1099-1106.

38. Howe M, Noble D. Effect of cyanide residue on vegetation bordering a Black Hills stream. Proc. S.D. Acad. Sci. 1985;64:112-122.

39. Al-Sultan SI. Sorghum halepenses and its cyanide content. Pak. J. Nutr. 2003;2(3):123-124.

40. Ahnstrom ZS, Parker DR. Development and assessment of a sequential extraction procedure for the fractionation of soil cadmium. Soil Sci. Soc. Am. J. 1999;63:1650-1658.

41. Aronstein BN, Maka A, Srivastava VJ. Chemical and biological removal of cyanides from aqueous and soil-containing systems. Appl. Microbial. Biotechnol. 1994;41:700-7007.

42. Cherryholmes KL, Cornils WJ, McDonald B, Splinter RC. Biological degradation of complex iron cyanides in natural aquatic systems. In: Cardwell RD, Purdy R, Bahner RC, eds. American Society for Testing and Materials. Philadelphia; 1985. p. 502-511.

43. Dursun AY, Calik A, Aksu Z. Degradation of ferrous (II) cyanide complex ions by Pseudomonas fluorescens. Proc. Biochem. 1999;34:901-908.
44. Qian X. Statistical Analysis and Evaluation of the Advanced Biomass and Natural Gas Co-Combustion Performance, Ph. D. Thesis, Morgan State University, Baltimore, MD, USA, 2019.

45. Marschner H. Mineral Nutrition of Higher Plants. London, UK: Academic Press; 1995.

46. Doudoroff P. Toxicity to fish of Cyanides and related compounds-: A review. Environmental Research Laboratory Office of Research and Develpment; U. S. Environmental Protection Agency Duluth, Minnesota; 1976. p. 83-134.

47. Darrah PR. Models of the rhizosphere. I. Microbial population dynamics around the root releasing soluble and insoluble carbon. Plant Soil. 1991;133:187-199.

48. Gerke J, Römer W, Jungk A. The excretion of citric and malic acid by proteoid roots of Lupinus albus L. effects on soil solution concentrations of phosphate, iron, and aluminium in the proteoid rhizosphere samples of an oxisol and a luvisol. J. Plant. Nutr. Soil Sci. 1994;157(4):289-294.

49. Zagury GJ, Oudjehani K, Deschênes L. Characterization and availability of cyanide in solid mine tailings from gold extraction plants. Sci. Tot. Environ. 2004;320:211-224.

50. Mansfeldt T, Leyer H, Barmettler K, Kretzschmar R. Cyanide leaching from soil developed from coking plant purifier waste as influenced by citrate. Vadose Zone J. 2004;3:471-479. 